\title{
THE VERSATILE NEWSPAPER SCRAPBOOK
}

\section{Martine Schoofs}

Using a scrapbook for newspaper clippings in class can motivate students to read and gather material from newspapers. In addition, the activities described below can help them learn about and through newspapers. I have found that these activities helped my students to learn how to read newspapers as well as develop an interest in current affairs. These activities also appealed to my students because they are based on the use of the different sections of the newspaper which address a wide range of interests.

In the following pages, I will describe several activities that ESL students can work through in their newspaper scrapbooks. These activities are appropriate for students from a low intermediate to an advanced level. Some of these activities can easily be adapted for use with students of different ability levels while others are only appropriate for students at one particular level.

For each of these activities, your students need a binder of some kind with removeable sheets on which they can paste whatever newspaper clippings they are working on. In addition to using weekday newspapers as a source of material, it is a good idea to collect as many weekend papers as you can because often they contain sections that are not available in weekday papers.

\section{Activity 1: The Sections of a Newspaper}

To help your students become more familiar with the content and general layout of the newspaper, give them the following worksheet to complete alone or with a partner.

Look in the newspaper and find:

The comics

The movie listings

Your horoscope

The T.V. schedule

The hockey results

A book review

The editorial

A birth announcement

Section Page

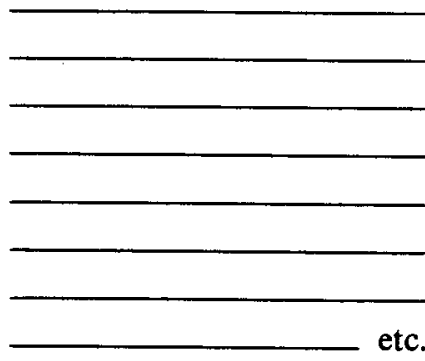

Activity 2: Your Own Birth Announcement

Ask your students to find the birth announcement section of the paper 
and have them cut out one or two announcements that particularly appeal to them to paste in their scrapbook. Have the students help you to make a list of the essential information to include in a birth announcement. This list should include items such as the date, place and time of birth as well as the baby's weight, length and given names.

Encourage your students to find a photograph of themselves as infants as well as information regarding their birth in order to write a birth announcement about themselves to include in a page of their scrapbook. Finally, have your students display these announcements in the classroom and give the group time to wander around and take a look at them and ask each other quesions related to the announcements.

\section{Activity 3: Headlines}

In order to familiarize your ESL students with the telegraphic style used in newspaper headlines, give them the following worksheet to complete as best they can.

Look in today's paper and see if you can find any headlines related to the following topics.

Topics

Section

Page

Natural disasters

War

Provincial politics

Strikes

Murders and Robberies, etc...

\section{Activity 4: Headline Mix and Match}

Give your students enough time to cut out 5 or 6 short articles from different papers on topics such as accidents, politics, sports, storms and special events. Then, have them paste the 5 or 6 headlines on one page of 
their scrapbook and the articles on another. Finally, working in pairs, each student asks his partner to match the headlines with the appropriate articles. If one of the students in the pair is having difficulty, the other should provide clues to make the matching task easier.

\section{Activity 5: W5}

Encourage your students to cut out an article of particular interest to them to paste on a page of their scrapbooks. Have them read the article and underline the information that seems the most important. Then, ask them to answer the $5 \mathrm{~W}$ questions (who, what, where, when and why) in relation to this article. Make sure that the students understand that they might not be able to answer all the $\mathrm{W}$ questions based on the information contained in the article they have chosen.

Doing this type of activity repeatedly will help your students to understand the general pattern found in many newspaper stories and help them develop efficient strategies for reading the newspaper.

\section{Activity 6: Ads}

To familiarize your students with different types of newspaper ads, have them cut out several ads and paste them in their scrapbooks under the following headings:

Food

Cars

Books

Vacation packages

Clothing

Furniture and appliances, etc...

Then, beside each ad have them indicate what has been highlighted in the various ads, e.g., the low price, the special guarantees, the quality of the product, the variety of colours and sizes, etc...

To wrap up, divide the students into groups of four or five and give each group a fixed budget and a list of items to buy from the various categories of advertised goods and services. Give them enough time to decide on what they would purchase and why. Then, have each group tell the class what they would buy with their allotted money and have them show the ads that influenced their decisions.

Sample cards: You have $\$ 130$ to buy the food and new clothes you need for the party you are giving tonight.

You have $\$ 5,000$ to spend on a vacation and furniture for your dining room and bedroom. 
You could also encourage your students to create their own ads for real or imaginary products. These ads should then be displayed in the classroom so that the students can see what each other has done. You could also have them vote on the funniest, most authentic looking or best illustrated ad or on the most interesting or useful new product advertised. After the contest, the students should paste their ads in their scrapbooks.

\section{Activity 7: The Classified Ads}

To familiarize your students with classified ads, have them go through this section in order to find particularly humourous, sad, catchy or unusual ads. Have them cut out the ads they have selected and paste them in their scrapbook leaving enough space to add titles, make comments, draw or paste pictures or photographs. Then, in small groups encourage the students to show each other the classified ads they have pasted in their scrapbooks. To wrap up, encourage each student to write a short ad to post on the school bulletin board. These ads might include items for sale or the offer of a service such as babysitting or snow clearing.

\section{Activity 8: Problem Solving}

Divide the students into groups of three or four and give each of them a letter written to an advice column. It could be a letter taken from a legal, consumer, health or personal advice column. Give the students some time to discuss the problem and to propose one or two alternative solutions. Then, have the students present both the problem and their suggested solutions to the rest of the class. When a group of students have finished their presentation the teacher should read the advice given by the columnist in the newspaper so the students can judge the relative merits of the various solutions offered.

This activity is a good way to familiarize foreign students, immigrants and refugees with certain aspects of Canadian life including public services, values, lifestyles and other controversial issues such as abortion and the generation gap.

\section{Activity 9: Horoscope}

Have your students cut out their horoscope and paste it onto a page of their newspaper scrapbooks. The next day, have them discuss the accuracy of the previous day's horoscope by comparing what was predicted and what actually happened to them that day.

On another day, students could cut out their horoscope from two different papers and compare them. 


\section{Activity 10: Class Paper}

Once your students are familiar with the layout and content of the newspaper, they can be encouraged to write their own class paper for distribution within the class or the school. Students could opt to write, edit or illustrate ads, articles, special interest stories, horoscopes, film or book reviews, advice columns, etc...

\section{Activity 11: Self-Evaluation Chart}

Give each student a self evaluation chart to fill in once they have participated in several of the activities described above. Doing this will make your students realize how well they understand the different parts of the paper and exactly what they can do with the various sections. It will also give you the feedback necessary to plan future activities related to the newspaper.

\section{Self-Evaluation Chart}

Name:

Yes No

I can find and read my horoscope.

I am familiar with the various sections of the newspaper.

I know where to find ads for cars for sale.

I can figure out what most headlines mean.

I can prepare a shopping list based on newspaper ads.

I can read and understand most short news stories.

I can read and understand some of the cartoons.

etc...

The preceding suggestions are merely a beginning. Students could also be asked to search for articles about many other topics such as an easy recipe, a film they would like to see, a famous movie star, strange fashions, a place they would like to go to for holiday, horoscopes, cartoons, an under-rated sport. Students could then be requested to take part in communicative or structure-oriented activities or they could be asked simply to cut out and glue their findings and be ready to explain their choice.

\section{THE AUTHOR}

Martine Schoofs completed her secondary and post-secondary education in Belgium. She immigrated to Canada in 1972 and has since received a diploma in translation and a B.Ed. in the teaching of ESL and FSL from McGill University in Montreal. 